\title{
Synthesis and Characterization of Some New Coordination Polymers of Schiff Base Derived from Furfural
}

\author{
M. H. Moustafa ${ }^{\#}$ and M. T. Abd-Allah \\ Department of Chemistry, Faculty of Science, Al-Azhar \\ University, Assiut Branch, Assiut, Egypt .
}

\begin{abstract}
OORDINATION polymers of the Schiff base N,N bis-(Furan-2ylmethylene)-1,4-phenylene diamine (BFMPDA) with zinc(II), cadmium(II) and cerium(III) have been prepared in dioxane medium. The optimal $\mathrm{pH}$ conditions for preparation the polymeric complexes were determined by potentiometry study. The stability constants of the complexes formed were calculated from the obtained potentiometric data. Polychelates polymers formed have been characterized on the basis of elemental analysis, infrared and electronic spectra. Glass transition temperature ( $\mathrm{Tg}$ ) and thermal stabilities of the polymers have been investigated by carrying out differential scanning calorimetry and thermogravimetric analysis. Electrical conductivity measurements of the synthesized polychelated polymers showed that they are insulators. The metal contents in all polymers are found to be consistent with 1:1 metal : ligand stoichiometry. The solubility and viscosity of the polymer complexes were also determined. The surface of the synthesized polymers was examined by scanning electron microscopy.
\end{abstract}

Keywords: Polychelates, Zinc, Cadmium and cerium, Schiff base, Synthesis, Characterization and Potentiometric.

Coordination polymers are now of great interest ${ }^{(1-6)}$. The first example of the coordination polymer was reported by Arimato et $a l^{(5)}$ The formation of chelates by poly has widely been used for concentration, separation and extraction of metal ions $^{(7-9)}$. The addition of metal ions to the polymers considerably improves the mechanical proportion and thermostability of the later. Many synthetic polymermetal complexes exhibit high catalytic activity simulating the action of metal enzymes ${ }^{(10-12)}$. Organometalic and inorganic transition-metal compound have been used widely as flame retardant and smoke suppressants, dramatically increasing the resistance of various polymer to ignition and burning ${ }^{(13)}$. Much work has been done on the preparation of polychelates derived from poly Schiff bases ${ }^{(14-18)}$. Abd-El$\mathrm{Aziz}^{(19-23)}$ and other authors ${ }^{(24-27)}$ presented reported several reviews on the syntheses and properties of metal containing and coordination polymers. Literature revealed that not any one have been reported the coordination polymers of the Schiff base ligand under investigation. Therefore, it was of interest to study the polymers of the

\footnotetext{
\#Author to whom correspondence should be addressed

E- mail: mahhassan1959 @ yahoo.com.
} 
Schiff base prepared from 1,4 phenylene diamine and furfural, because of its strong tendency to coordinate with the metal ions. Potentiometry being the classical and suitable method was used to search for the true equilibria, composition and the stability of the complex species in solution. This technique was used for determination the stability of coordination polymers ${ }^{(28,29)}$. Spectroscopic ${ }^{(30)}$, fluorescence spectra ${ }^{(31)}, \mathrm{X}$-ray analysis ${ }^{(32)}$, ionic conductivity ${ }^{(33)}, \mathrm{pH}^{3}$-effects on the complex formation ${ }^{(34)}$, thermogravimetry ${ }^{(35)}$..., etc have been used for the characterization of the coordination polymers and the system is apparently well known. The present paper describes the optimization of the complexation conditions reactions of N,N bis-(Furan-2-ylmethylene)-1,4-phenylene diamine (BFMPDA) towards $\mathrm{Zn}(\mathrm{II}), \mathrm{Cd}(\mathrm{II})$ and $\mathrm{Ce}(\mathrm{III})$ ions. The optimal $\mathrm{pH}$ values for the formation of the polymers were limited from potentiometric titrations ${ }^{(36,37)}$. The $\mathrm{pH}$ titration technique of Irving and Rossotti ${ }^{(38)}$ was employed in this study. The measurements were carried out at $25^{\circ} \mathrm{C}$, ionic strength of $0.1 \mathrm{~mol} \mathrm{dm}^{-3}\left(\mathrm{KNO}_{3}\right)$ in $50 \%(\mathrm{v} / \mathrm{v})$ dioxane-water solution. The Schiff base acts as a tetradentate ligand bonding through the oxygen and nitrogen atoms. The resulting coordination polymers were characterized by elemental analysis, infrared and electronic spectra. Physical properties such as viscosity, solubility and electrical conductivity were also studied. High glass transition temperature indicated that the complexes in chain polymer. Electrical conductivity measurements proved that the complexes are non conducting polymers. The polymeric complexes examined by scanning electron microscopy (SEM).

Materials

\section{Experimental}

All chemicals were Analar chemically pure grade. The chemicals 1,4phenylene diamine (para amino aniline), furfural (furaldehyde) which used for preparation the ligand N,N bis-(Furan-2-ylmethylene)-1,4-phenylene diamine (BFMPDA) were purchased from Sigma- Aldrich Chemicals Co., USA and were used as received. Different metal salts: zinc nitrate, cadmium nitrate tetrahydrate and cerium nitrate hexahydrate were purchased from Merck (Germany). $\mathrm{HNO}_{3}$, potassium nitrate, potassium hydroxide, potassium hydrophethalate, Borax, 1,4 dioxane, dimethylsulfoxide (DMSO) and dimethyl formamide (DMF) of Analar products were obtained from Sigma- Aldrich chem.Co., USA.

\section{Apparatus}

$\mathrm{pH}$ measurements were carried out using a Corning $215 \mathrm{pH}$ meter with a combined glass electrode. The glass electrode was calibrated before each titration with two Merck standard buffer solutions, first with the $\mathrm{pH} 7.0$ followed by a $\mathrm{pH}$ 4.0 at $25^{\circ} \mathrm{C}$ by coupling the titration cell with a thermostatic bath set at this temperature. The elemental analysis were carried on a Perkin-Elmer $240 \mathrm{C}$ instrument. The electronic spectra of DMF solutions of the ligand (BFMPDA) and its different metal complexes were recorded on a Perkin-Elmer (Lambda 35) computerized spectrophotometer equipped with $1 \mathrm{~cm}$ matched quartz cells. The Infrared spectra were performed by a Fourier transform Infrared spectrometer (FT-IR) analysis in the region $400-4000 \mathrm{~cm}^{-1}$ with Jasko 480 spectrometer using

Egypt. J. Chem. 54, No.3 (2011) 
potassium bromide disk technique. NMR spectra were recorded in DMSO on Varian EM-360 L, $60 \mathrm{MH}_{\mathrm{Z}}$, NMR spectrometer and JEOL FX 90 Q Fourier transform NMR. Thermogravimetric analysis TGA and differential scanning calorimeter DSC were carried out with a Schimadzu Thermal Analyzer $50 \mathrm{H}$ at heating rate of $10^{\circ} \mathrm{C} / \mathrm{min}$ in nitrogen atmosphere up to $750{ }^{\circ} \mathrm{C}$. The solubility of polymers was determined using $0.01 \mathrm{~g}$ in $3-5 \mathrm{ml}$ of solvent at room temperature. The inherent viscosities of the polymers solutions $(0.5 \% \mathrm{w} / \mathrm{v})$ in DMF were determined at $30^{\circ} \mathrm{C}$ using Ubbelohde Suspended Level Viscometer. Conductivities were measured at $25^{\circ} \mathrm{C}$ using HIOKI $3532-50$ LCR Hi TESTER computerized electrometer as pellets between two standard graphite electrodes. The isolated polymer systems were investigated by the scanning electron microscopy (SEM) with a JEOL JSM 5400 LV.

Synthesis of N,N bis-(Furan-2-ylmethylene)-1,4-phenylenediamine (BFMPDA)

To a $500 \mathrm{~cm}^{3}$ round-bottom flask a $100 \mathrm{ml}$ ethanolic solution of 1,4phenylenediamine $(0.01 \mathrm{M})$ treated with furaldehyde $(0.02 \mathrm{M})$. The mixture was stirred at room temperature for one hour after that the mixture was refluxed at $70^{\circ} \mathrm{C}$ on a water bath for three hours. On cooling a black compound precipitated out. The formed black crystals of the Schiff base ligand were collected and observed that it dissolved only in dioxane solution. The product was filtered, washed with ethanol and dried in air, yield $82 \%$, m.p. $170^{\circ} \mathrm{C}$. ${ }^{1} \mathrm{HNMR}$ (in DMSO): $\delta 8.0-8.5(\mathrm{~s}, 2 \mathrm{H}, \mathrm{CH}=\mathrm{N}) ; 7.25(\mathrm{~m}, 4 \mathrm{H} \varphi) ; 7.62(\mathrm{~s}, 2 \mathrm{H}, 5 \mathrm{H}$ of $\mathrm{Fu}) ; 6.57$ (s, $2 \mathrm{H}, 4 \mathrm{H}$ of $\mathrm{Fu}) ; 6.98\left(\mathrm{~s}, 2 \mathrm{H}, 3 \mathrm{H}\right.$ of $\mathrm{Fu}$ ). Analysis calculated for $\mathrm{C}_{16} \mathrm{H}_{12} \mathrm{~N}_{2} \mathrm{O}_{2}$ : C, $72.23 \% ; \mathrm{H}, 4.54 \%$; N $10.61 \%$; O, 12.12\%. Found: C, 72.73\%; H, 4.52\%; N, $10.63 \%$; O, $12.23 \%$. Mass spectrum of the Schiff base ligand N,N bis-(Furan-2ylmethylene)-1,4-phenylene diamine (BFMPDA) (Fig. 1) exhibited a molecular ion peak at $\mathrm{m} / \mathrm{z} 187$; with abase peak at $264.76 \mathrm{C} 100 \%$.

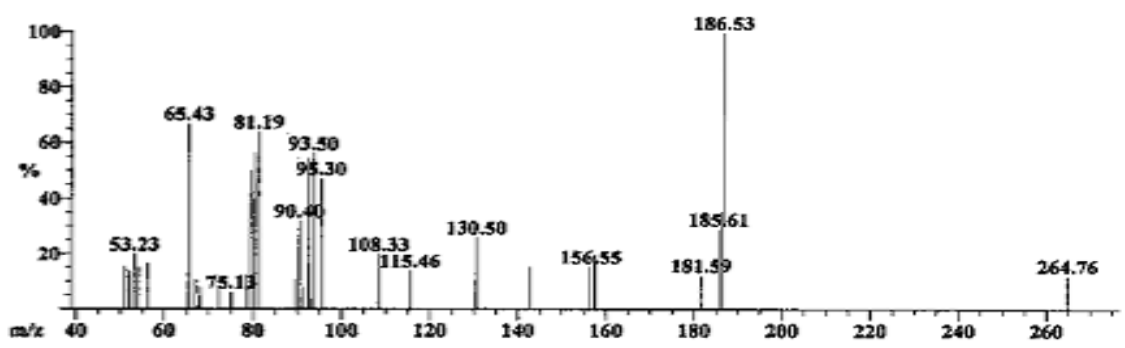

Fig. 1. Mass spectrum of BFMPDA.

The condensation involved in this study is the typical Schiff reaction take place as follow:

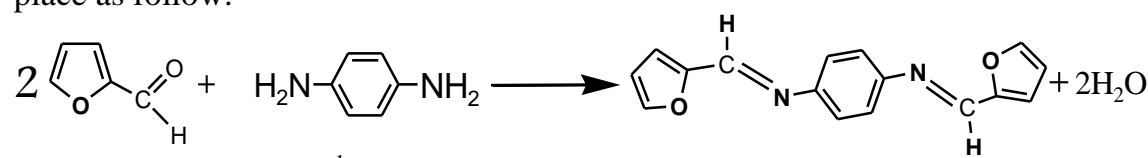

Figures 1,2. show ${ }^{1}$ HNMR and FT-IR spectra of the product confirmed its regular linear structure. 


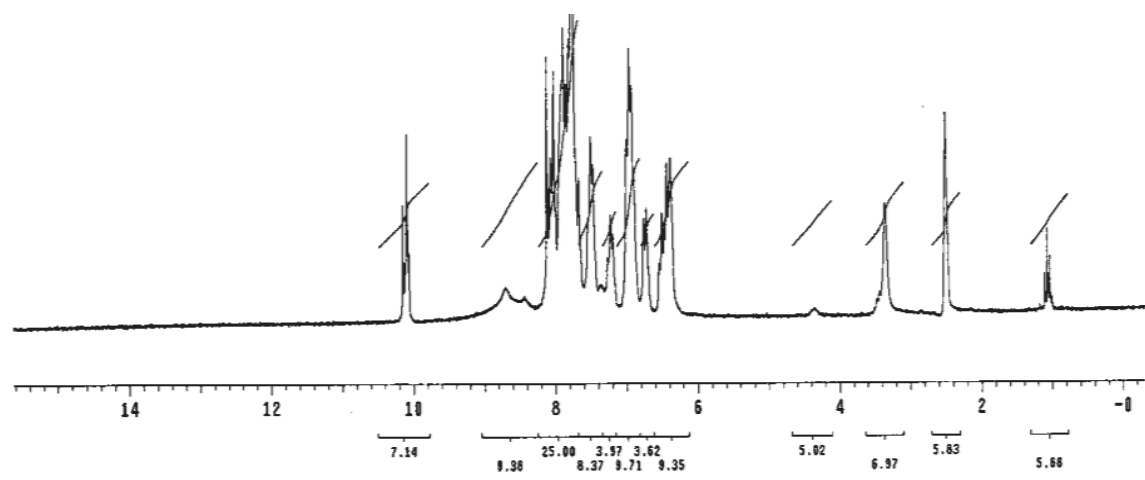

Fig. 2. ${ }^{1} \mathrm{H}-\mathrm{NMR}$ spectrum (in DMSO) of BFMPDA.

\section{Potentiometric titrations}

Dioxane and doubly distilled water were used for the preparation of the solutions. Potassium nitrate $(1.0 \mathrm{M})$ and standard solutions $(0.01 \mathrm{M})$ of potassium hydroxide and nitric acid were prepared. Standard stock solutions of $\mathrm{Zn}$ (II), Cd(II) or Ce(II) 0.02 $\mathrm{M}$ were prepared ${ }^{(39)}$. Each solution was diluted so as to prepare the standard solution. The ligand BFMPDA solution was prepared in dioxane, the ligand and the metal salt concentration was $2.5 \times 10^{-3} \mathrm{M}$. The potentiometric equilibrium measurements were made on $5.00 \mathrm{~cm}^{3}$ of the ligand solutions diluted to a final volume of $50.00 \mathrm{~cm}^{3}$, in the presence and absence of metal ion for which the $C_{M}: C_{L}$ ratio were $1: 1$ and 1:2 in $50 \%$ (v/v) dioxane-water solution, at $25^{\circ} \mathrm{C}$ and the ionic strength was adjusted with $0.1 \mathrm{~mol} \mathrm{dm}^{-3}\left(\mathrm{KNO}_{3}\right)$ in each case. The $\mathrm{pH}$ titration technique of Irving and Rossotti ${ }^{(38)}$ was applied. The $\mathrm{pH}$ values in the partially aqueous solutions were corrected by using the equation which described previously ${ }^{(40)}$. All the dissociation and the complex formation constants were determined using the SUPERQUAD program $^{(41)}$. The program has been used to calculate acidity constants in systems previously studied ${ }^{(42-44)}$. The protons association constants $\mathrm{pK}_{1}$ and $\mathrm{pK}_{2}$ were determined by potentiometric titration of $50 \mathrm{ml}$ of 0.30 mmol $\mathrm{HNO}_{3}$ and $\mathrm{KNO}_{3}$ $(\mathrm{I}=0.1 \mathrm{M})$ with carbonate free potassium hydroxide. The stability constants for the binary $\mathrm{Zn}(\mathrm{II}), \mathrm{Cd}(\mathrm{II})$ or $\mathrm{Ce}(\mathrm{III})$-BFMPDA complexes were computed from titration curves in which the metal concentration was $8 \times 10^{-5} \mathrm{M}$. Multiple titrations were carried out for each system.

\section{Syntheses of $\mathrm{Zn}(I I), C d(I I)$ and $C e(I I I)-(B D M P D A)$ binary system}

All the coordination complexes were prepared by a condensation between equimolar amounts of the ligand (BFMPDA) in dioxane solution with nitrate salt of zinc(II), cadmium(II) or cerium(III) in $2.0 \mathrm{mmol}$ in of doubly distilled water for $24 \mathrm{hr}$, with adjusted $\mathrm{pH}$ degree at $6.30,7.9$ and 6.10, respectively by adding aqueous potassium hydroxide. Every mixture was stirred under with heating on a water bath at a constant temperature of $70^{\circ} \mathrm{C}$ then concentrated by evaporation to its half volume and left to cool to room temperature overnight. Each complex was filtered off on a water pump and the obtained metal chelates washed several times with doubly distilled water, $\mathrm{Et}_{2} \mathrm{O}$, and ethanol and finally dried in vacuum over $\mathrm{P}_{4} \mathrm{O}_{10}$.

Egypt. J. Chem. 54, No.3 (2011) 


\section{Potentiometric titrations}

\section{Results and Discussion}

The acid-base properties of the Schiff base ligand N,N bis-(Furan-2ylmethylene)-1,4-phenylene diamine (BFMPDA) in 50\% dioxane-water mixture solution, Temp. $25^{\circ} \mathrm{C}, \mathrm{I}=0.1 \mathrm{M}\left(\mathrm{KNO}_{3}\right)$; yield three forms, $\mathrm{H}_{2} \mathrm{~L}^{++}, \mathrm{HL}^{+}$and $\mathrm{L}$. The predominant form of the ligand is the dicationic species, which undergoes stepwise ionization on increasing the $\mathrm{pH}$ of solution. $\mathrm{pK}_{1}$ and $\mathrm{pK}_{2}$ values for (BFMPDA) are 5.9 and 10.77, respectively. The protonation equilibria of ligand (L) can be represented by Eq. (1) and (2).

$$
\begin{array}{lll}
\mathrm{H}_{2} \mathrm{~L}^{++} & \stackrel{\mathrm{pK}_{1}}{\mathrm{pK}_{2}} & \mathrm{HL}^{+}+\mathrm{H}^{+} \ldots \ldots \ldots \\
\mathrm{HL}^{+} & = & \mathrm{L}+\mathrm{H}^{+} \ldots \ldots \ldots
\end{array}
$$

The obtained curves showed the potentiometric $\mathrm{pH}$ profiles of a solution of $2.5 \times 10^{-4} \mathrm{M}$ of BFMPDA in the absence and in the presence of various metal ions. The potentiometric titration curve for BFMPDA in the cationic form $\mathrm{H}_{2} \mathrm{~L}^{2+}$ shows a two inflections at $\mathrm{a}=1$ followed by a moderate inflection at $\mathrm{a}=2(\mathrm{a}=$ moles of base added per mole of ligand ) corresponding the stepwise dissociation constants of the ligand. The titration curve for a system containing 1:1 or 1:2 molar ratio of $\mathrm{Zn}(\mathrm{II})$, $\mathrm{Cd}(\mathrm{II})$ or $\mathrm{Ce}$ (III) and dicationic BFMPDA exhibits two inflections at $\mathrm{m}=1$ and $\mathrm{m}=2$ $(\mathrm{m}=$ moles of base added per mole of metal ion) indicating the formation of mono and bis-binary complexes. But the ligand BFMPDA containing two centers of binding groups each one has $\mathrm{O}$ and $\mathrm{N}$ atoms, this means that every ligand molecule bonded with two metal ions gives two five member rings. This proves that the composition of the polychelates confirmed as 1:1 (M : L) complex. The study revealed the optimal $\mathrm{pH}$ conditions for formation of a complex with $\mathrm{Zn}$ (II), $\mathrm{Cd}$ (II) or $\mathrm{Ce}(\mathrm{III})$ : BFMPDA ratio of $1: 1$ is $6.30,7.9$ and 6.10 , respectively. The stability constants for binary complexes, as depicted from the titration curves are given in Table 1. The complexed species found in this work for BFMPDA and the studied metal ions can be represented by the following Eqs. 3 and 4:

$$
\begin{aligned}
& \mathrm{M}+\mathrm{L} \rightleftharpoons \mathrm{ML}, \quad \mathrm{K}_{\mathrm{ML}}^{\mathrm{M}}=\frac{[\mathrm{ML}]}{--\mathrm{M}^{2} \cdot[\mathrm{L}]},
\end{aligned}
$$

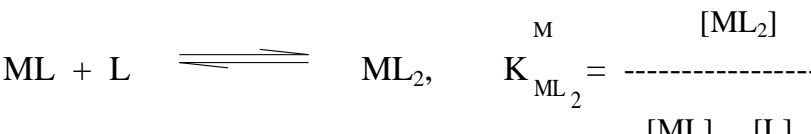

\section{Absorption spectra}

The absorption spectra of $2.5 \times 10^{-4} \mathrm{M}$ solution of the reagent (BFMPDA) were recorded as the dependence of $\mathrm{A}=\mathrm{F}(\lambda)$ for various $\mathrm{pH}$ in the presence of $50 \%$ dioxane. The spectra showed two absorption bands with the $\mathrm{pH}$ range 3-11.5. The first band observed at $\mathrm{pH}$ range $3-8.3$ at $\lambda=340 \mathrm{~nm}$ and is presumably due to the absorption of dicationic molecules of the compound. At higher $\mathrm{pH}$ values > 8.4 the absorption decreases in intensity and a new band appears at $360 \mathrm{~nm}$. This 
band corresponding to absorption by the monocationic form of BFMPDA. The wavelength U.V.-visible region spectra suggests that the contribution to conjugation, and this to the reduction of the energy association with the lowest $\pi$ $\pi^{*}$ transition. The absorption spectra of M-BFMPDA in 1: 1 molar ratio $\left(2.5 \times 10^{-4} \mathrm{M}\right)$ complex with the reagent as reference in dioxane are characterized by an absorption maxima at $420 \mathrm{~nm}$ for $\mathrm{Zn}(\mathrm{II}), \mathrm{Cd}(\mathrm{II})$ and $\mathrm{Ce}$ (III) complexes. On comparison the electronic absorption spectra of the free ligand BFMPDA with those of the chelates of $\mathrm{Zn}$ (II) or $\mathrm{Cd}(\mathrm{II})$ or $\mathrm{Ce}(\mathrm{III})$ proved shifted of the ligand spectrum band at $360 \mathrm{~nm}$ to longer wavelength showed that coordination of the metal ions to the ligand.

TABLE 1. Logarithms of the stability constants of binary complexes containing 1:1 ratio of metal ions with the schiff base $\mathrm{N}, \mathrm{N}$ bis-(furan-2-ylmethylene)-1,4phenylenediamine(BFMPDA).

\begin{tabular}{|c|c|c|c|}
\hline Metal ion & $\log k_{M L}^{M}$ & $\log k_{M L_{2}}^{M L}$ & $\log \beta_{M L_{2}}^{M L}$ \\
\hline $\mathrm{Zn}(\mathrm{II})$ & 8.85 & 8.34 & 17.19 \\
\hline $\mathrm{Cd}(\mathrm{II})$ & 6.52 & 6.26 & 12.78 \\
\hline $\mathrm{Ce}(\mathrm{III})$ & 8.58 & 8.25 & 16.83 \\
\hline
\end{tabular}

Microchemical analysis and electrical conductivity

The molar conductance values of $10^{-3} \mathrm{M}$ of $1: 1$ (M:L) ratio of zinc(II), cadmium(II) and cerium(III)-(BFMPDA) in dioxane solution, at room temperature were found 4.1, 3.98 and $4.04 \mathrm{ohm}^{-1} \mathrm{~mol}^{-1} \mathrm{~cm}^{-1}$, respectively. This indicates that all polychelates are insulator.

The electrical conductivities of the various complexes at room temperature are summarized in Table 2 . The electrical conductivity of the divalent $\mathrm{Zn}$ (II) and $\mathrm{Cd}(\mathrm{II})$ and the trivalent $\mathrm{Ce}$ (III) metal ion complexes lies in the range $6.555 \times 10^{-12}$ and $6.784 \times 10^{-10} \Omega^{-1} \mathrm{~cm}^{-1}$. The data reveals that the coordination polymers are poor electrical conductors. The Microchemical analysis data are listed in Table 2, and help for suggested the structure formula of the poly chelates. The data reveals that the coordination polymers are poor electrical conductors.

\section{FT-IR Spectrum}

The FT-IR spectrum of the ligand BFMPDA (Fig. 3) shows the important peaks at $3100,1509,1013,824,750 \mathrm{~cm}^{-1}$ which attributed to the stretching of the five heterocycle ring ( furan ring breathing mode $)^{(45)}$. The weak peaks at 2924 and $2900 \mathrm{~cm}^{-1}$ were attributed to the asymmetrical and symmetrical C-H stretching of methyline groups. Another important peak occurs at $1617 \mathrm{~cm}^{-1}$ attributed to $v_{(\mathrm{C}=\mathrm{N})}$ stretching mode ${ }^{(46)}$. The ligand BFMPDA is expected to act as a tetradentate with possible coordination sites being azomethinic-nitrogen and heterocyclic oxygen. By a comparison of its spectra with those of the polychelates (Fig. 4-6), the band occurs at $1617 \mathrm{~cm}^{-1}$ which attributed to $v_{(\mathrm{C}=\mathrm{N})}$ stretching mode, this band is shifted to a lower wave number and appears at 1607,1600 and $1590 \mathrm{~cm}^{-1}$ in the IR spectrum of $\mathrm{Zn}(\mathrm{II}), \mathrm{Cd}(\mathrm{II})$ and $\mathrm{Ce}$ (III) complex, respectively. This indicates the involvement of the $\mathrm{N}$-atom of the azomethine in coordination ${ }^{(4)}$. The peaks at Egypt. J. Chem. 54, No.3 (2011) 
$3100,1509,1013,824,750 \mathrm{~cm}^{-1}$ assigned to the ring stretching of the five membered ring undergoes, the peak at $3100 \mathrm{~cm}^{-1}$ disappeared in the spectra of all coordination polymers, while the peak at $1509 \mathrm{~cm}^{-1}$ is found in the same region due to a decrease in electron density of the ring on complexation. The appearance of new strong band in the spectra of the complexes at $1385 \mathrm{~cm}^{-1}$ is attributed to the free nitrate ion. The absorption bands occurring in the regions $1130-1115$ and $850-828 \mathrm{~cm}^{-1}$ which are not present in the spectra of free ligand, suggest the nitrate groups are coordinated mono dentately in the subject complexes. The presence of water can be detected by the characteristic band in the $3562-3360 \mathrm{~cm}^{-1}$ region in the spectra of the three complexes. The stretching vibrations $\mathrm{v}_{(\mathrm{M}-\mathrm{N})}$ are observed around 500 and the bands in the far infrared region in the $468-400$ range are assigned to $v_{(\mathrm{M}-\mathrm{O})}$ modes. All the complexes have similar IR spectra (Table 3), indicating that they have similar structures.

TABLE 2. Some physical and electrical conductivity of the ligand BFYMDA and Its $\mathrm{Zn}(\mathrm{II}), \mathrm{Cd}(\mathrm{II})$ and $\mathrm{Ce}(\mathrm{III})$ polychelates.

\begin{tabular}{|c|c|c|c|c|c|c|c|c|c|}
\hline \multirow{2}{*}{$\begin{array}{l}\text { Chelate Emperical } \\
\text { Formula }\end{array}$} & \multirow[b]{2}{*}{ Colour } & \multirow{2}{*}{$\begin{array}{c}\text { Yield } \\
\%\end{array}$} & \multirow{2}{*}{$\begin{array}{l}\text { M.P } \\
\left({ }^{\circ} \mathrm{C}\right)\end{array}$} & \multicolumn{3}{|c|}{ Found (Calc.) \% } & \multirow[b]{2}{*}{$\begin{array}{l}{ }^{\mathrm{a}} \eta \mathrm{mh} \\
(\mathrm{dl} / \mathrm{g})\end{array}$} & \multirow{2}{*}{$\begin{array}{c}\text { Electrical } \\
\text { Conductivity } \\
\left(\mathrm{ohm} \mathrm{cm} \mathbf{c m}^{-1}\right)\end{array}$} & \multirow{2}{*}{${ }^{\mathrm{b}} \mathbf{M} . \mathbf{W}$. } \\
\hline & & & & $\overline{\mathrm{C}}$ & $\mathbf{H}$ & $\mathbf{N}$ & & & \\
\hline $\mathrm{C}_{16} \mathrm{H}_{12} \mathrm{~N}_{2} \mathrm{O}_{2}$ & black & 82 & 170 & $\begin{array}{l}72.72 \\
75.88\end{array}$ & $\begin{array}{c}4.54 \\
5.10\end{array}$ & $\begin{array}{r}10.60 \\
8.90\end{array}$ & 0.89 & $7.82 \times 10^{-13}$ & 264 \\
\hline$\left[\mathrm{ZnC}_{16} \mathrm{H}_{10} \mathrm{~N}_{2} \mathrm{O}_{2} \cdot \mathrm{H}_{2} \mathrm{O}\right]_{\mathrm{n}}$ & black & 85 & $>360$ & $\begin{array}{l}55.59 \\
60.81\end{array}$ & $\begin{array}{l}3.47 \\
4.08\end{array}$ & $\begin{array}{l}8.11 \\
7.09\end{array}$ & 0.54 & $7.112 \times 10^{-11}$ & 345.39 \\
\hline$\left[\mathrm{CdC}_{16} \mathrm{H}_{10} \mathrm{~N}_{2} \mathrm{O}_{2} \cdot \mathrm{H}_{2} \mathrm{O}\right]_{\mathrm{n}}$ & $\begin{array}{c}\text { dark } \\
\text { brown }\end{array}$ & 89 & $>360$ & $\begin{array}{c}48.93 \\
53.99 \\
53.97\end{array}$ & $\begin{array}{c}3.06 \\
3.57 \\
3.62\end{array}$ & $\begin{array}{c}7.14 \\
6.27 \\
6.3\end{array}$ & 0.46 & $6.555 \times 10^{-12}$ & 392.41 \\
\hline$\left[\mathrm{CeNO}_{3} \mathrm{C}_{16} \mathrm{H}_{10} \mathrm{~N}_{2} \mathrm{O}_{2} \cdot \mathrm{H}_{2} \mathrm{O}\right]_{\mathrm{n}}$ & $\begin{array}{c}\text { dark } \\
\text { brown }\end{array}$ & 87 & $>360$ & $\begin{array}{l}42.14 \\
44.33 \\
44.49\end{array}$ & $\begin{array}{l}2.63 \\
2.94 \\
2.98\end{array}$ & $\begin{array}{c}9.22 \\
5.1 \\
5.1\end{array}$ & 0.47 & $6.784 \times 10^{-10}$ & 455.65 \\
\hline
\end{tabular}

${ }^{a} \eta=$ inherent viscosity

${ }^{\mathrm{b}}$ M.W. = molecular weight of repeat unit.

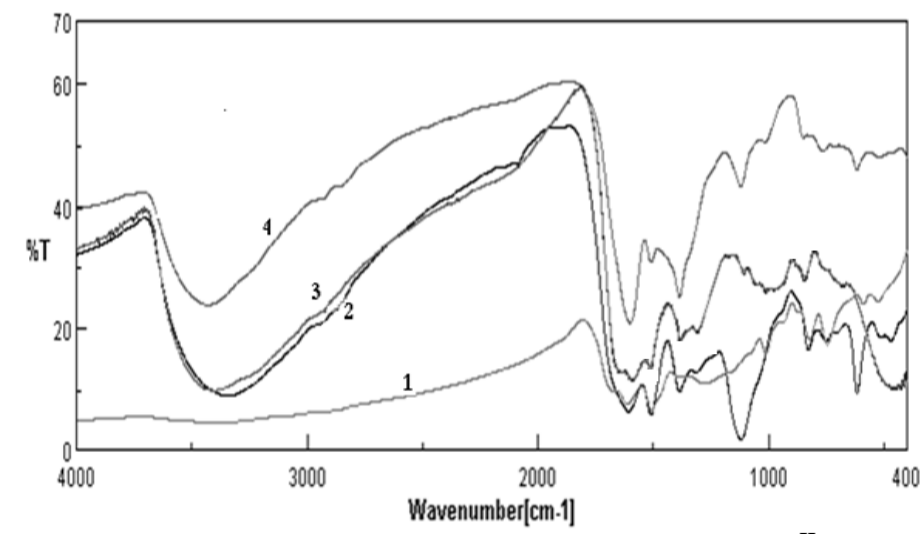

Fig. 3. FT-IR absorption spectra of (1) the ligand BFMPDA, (2) $\mathrm{Zn}^{\mathrm{II}}$-BFMPDA, (3) Ce ${ }^{\text {III }}$-BFMPDA and (4) Cd ${ }^{\text {II }}$-BFMPDA. 


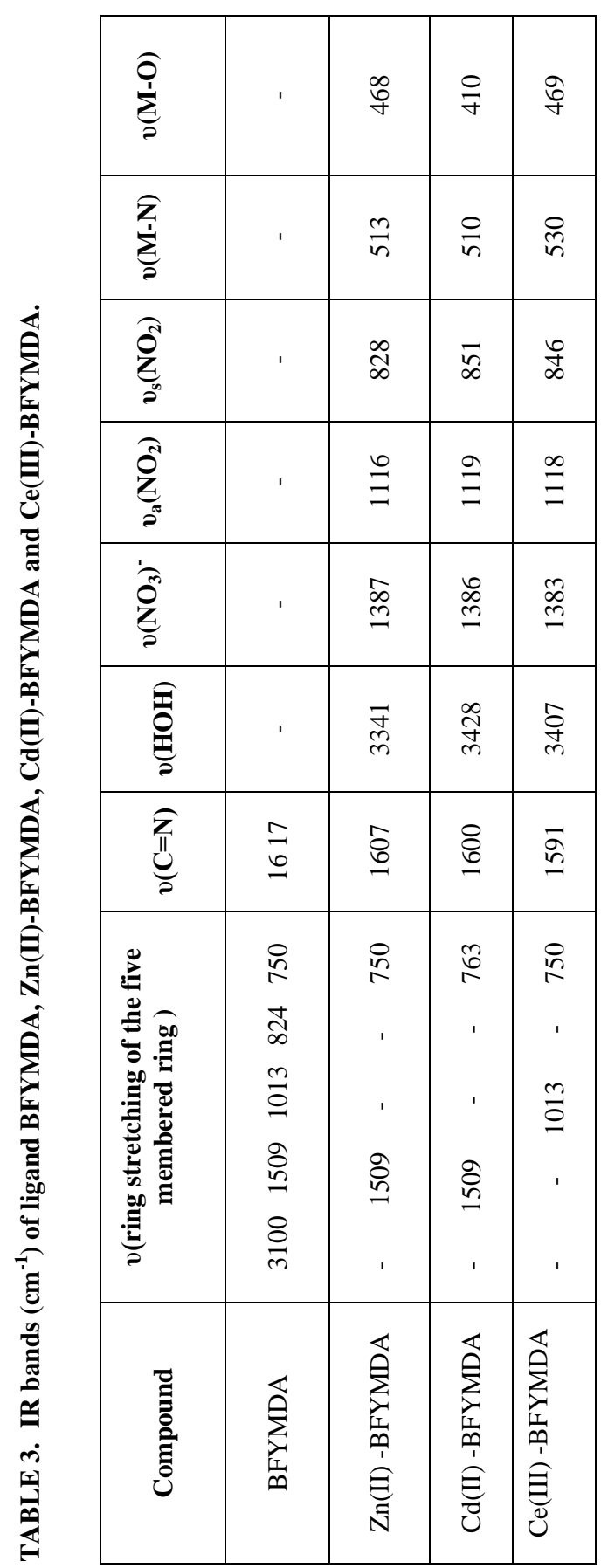

Egypt. J. Chem. 54, No.3 (2011) 
Thermal analysis and differential scanning calorimeter

In order to obtain convincing evidence for suggested formula of synthesized complexes, thermogravimetric analysis TGA of these complexes have been carried out under nitrogen atmosphere. Thermogravimetry of three polychelates reveals the variation of thermal stability. The obtained TG curves (Fig.4) show that the three polychelates of BFMPDA decompose in a similar way, the weight loss corresponds to amounts $3.7 \%, 3.5 \%$ and $5.32 \%$ can be attributed to elimination of one, one and two crystallization water molecules for $\mathrm{Zn}(\mathrm{II}), \mathrm{Cd}(\mathrm{II})$ and $\mathrm{Ce}(\mathrm{III})$ complex, respectively. The weight loss in the temperature $120-190^{\circ} \mathrm{C}$ can be attributed to the removal of one coordinated water molecule. The thermal decomposition of these curves suggests that above $200{ }^{\circ} \mathrm{C}$ the compounds start to loss mass with partial evaporation of the organic ligand. The TG thermograms indicate that the polychelates decompose in two stages, and that the rate of degradation in the second stage is fast compared to the first stage. The other decomposition step, the weight loss can be attributed to the removal of $\mathrm{NO}_{2}$ molecules of the two and three coordinated nitrate groups for $\mathrm{Zn}(\mathrm{II}), \mathrm{Cd}(\mathrm{II})$ and $\mathrm{Ce}(\mathrm{III})$ complex, respectively. The metal oxide is the finally product and the TG data shows that the complex Ce-BFYMDA system is the most thermal stability.

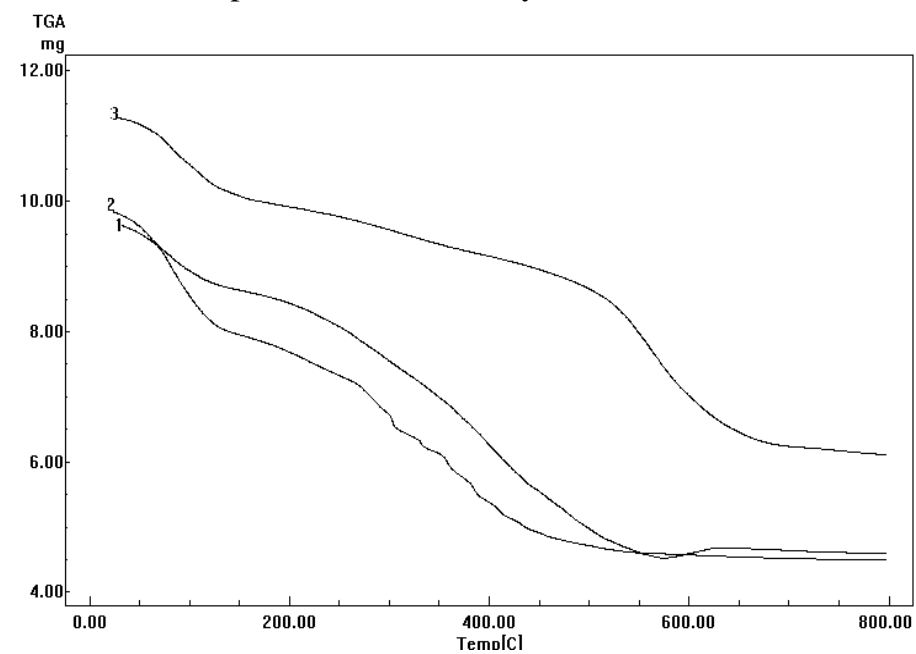

Fig. 4. Thermogravimetric curves of polychelates: 1) $\left.\mathrm{Zn}(\mathrm{BFYMDA})\left(\mathrm{NO}_{3}\right)_{2}\left(\mathrm{H}_{2} \mathrm{O}\right), 2\right)$ $\left.\mathrm{Cd}(\mathrm{BFYMDA})\left(\mathrm{NO}_{3}\right)_{2}\left(\mathrm{H}_{2} \mathrm{O}\right), 3\right) \mathrm{Ce}(\mathrm{BFYMDA})\left(\mathrm{NO}_{3}\right)_{3}\left(\mathrm{H}_{2} \mathrm{O}\right)$.

In the DSC curves the glass transition zone was determined as the temperature range between two intersection points of the base line with the extrapolated sloping portion of the thermogram, which resulted from a heat capacity change. Tg was defined as the inflection point of the curve. The DSC thermogram of the resulting polychelates Zn-BFMPDA, Cd-BFMPDA and $\mathrm{Ce}-$ BFMPDA samples is shown in Fig. 5. The values of their glass transition temperature (Tg) are 135, 125 and 110 for $\mathrm{Zn}(\mathrm{II}), \mathrm{Cd}(\mathrm{II})$ and $\mathrm{Ce}(\mathrm{III})$ polychelates, respectively. The synthesized coordination polymers show a single $\mathrm{Tg}$, showing the absence of formation of mixture of homopolymer.

Egypt. J. Chem. 54, No.3 (2011) 


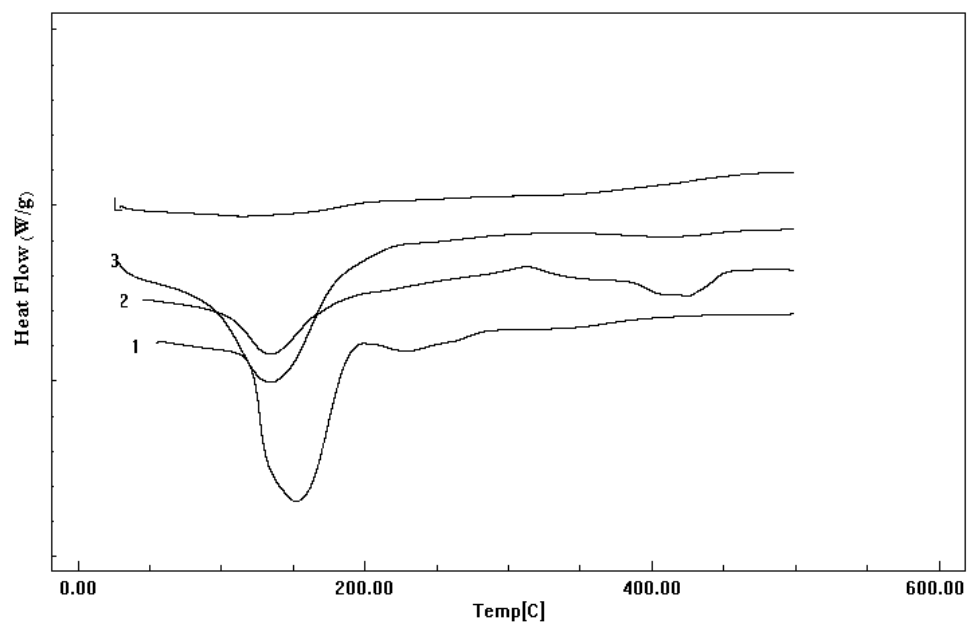

Fig. 5. DSC Thermograms of Coordination polymers: 1) $\mathrm{Zn}(\mathrm{BFYMDA})\left(\mathrm{NO}_{3}\right)_{2}\left(\mathrm{H}_{2} \mathrm{O}\right)$, 2) $\left.\mathrm{Cd}(\mathrm{BFYMDA})\left(\mathrm{NO}_{3}\right)_{2}\left(\mathrm{H}_{2} \mathrm{O}\right), 3\right) \mathrm{Ce}(\mathrm{BFYMDA})\left(\mathrm{NO}_{3}\right)_{3}\left(\mathrm{H}_{2} \mathrm{O}\right)$.

Scanning electron microscopic (SEM) images of the resulting polychelates Zn-BFMPDA, Cd-BFMPDA and Ce-BFMPDA samples are shown in Fig. 6-8. Hence, the morphological features of the surface are anther convincing evidence proved that the above complexes are coordination polymers.

The analytical results indicate that the synthesized coordination polymers posses the general formulas [Zn (BFYMDA) $\left.\left(\mathrm{NO}_{3}\right)_{2}\left(\mathrm{H}_{2} \mathrm{O}\right)\right]_{\mathrm{n}},[\mathrm{Cd}$ (BFYMDA) $\left.\left(\mathrm{NO}_{3}\right)_{2}\left(\mathrm{H}_{2} \mathrm{O}\right)\right]_{\mathrm{n}}$ and $\left[\mathrm{Ce}(\mathrm{BFYMDA})\left(\mathrm{NO}_{3}\right)_{3}\left(\mathrm{H}_{2} \mathrm{O}\right)\right]_{\mathrm{n}}$

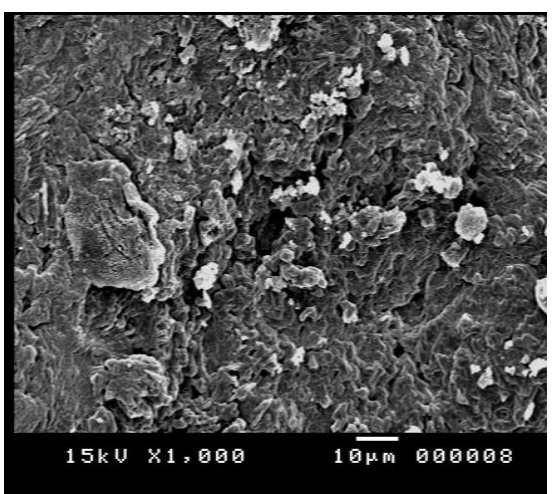

(a)

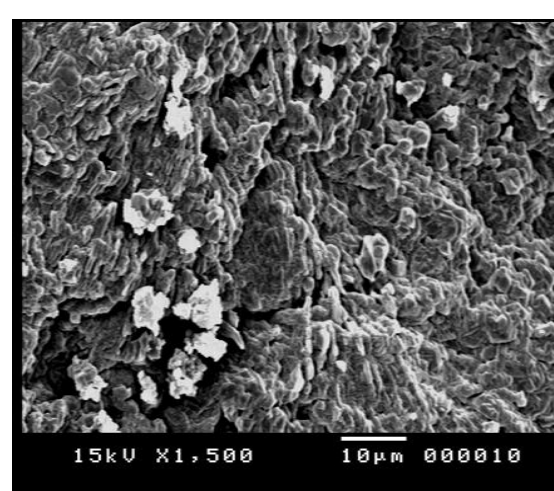

(b)

Fig. 6. SEM micrograph of $(\mathrm{Zn}-\mathrm{BFYMDA})_{\mathrm{n}}$ coordination polymer film = a) electrode side, magnification 1000x, bar $=10 \mu \mathrm{m}$; b) electrode side, magnification 1500x, bar $=10 \mu \mathrm{m}$.

Egypt. J. Chem. 54, No.3 (2011) 


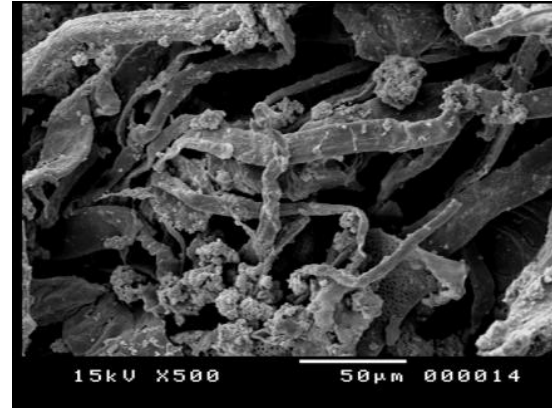

(a)

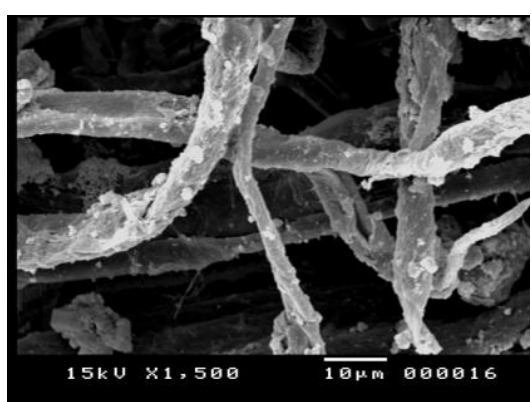

(b)

Fig. 7. SEM micrograph of $(\text { Cd-BFYMDA })_{n}$ coordination polymer film = a) electrode side, magnification $1000 x$, bar $=10 \mu \mathrm{m}$; b) electrode side, magnification $1500 x$, bar $=10 \mu \mathrm{m}$.

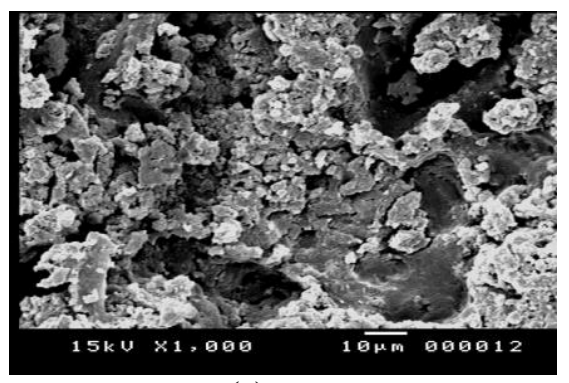

(a)

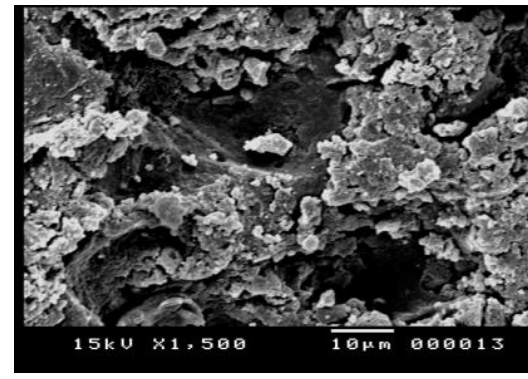

(b)

Fig. 8. SEM micrograph of $(\mathrm{Zn}-\mathrm{BFYMDA})_{\mathrm{n}}$ coordination polymer film= a)electrode side, magnification 1000x, bar $=10 \mu \mathrm{m}$; b) electrode side, magnification $1500 \mathrm{x}$, bar $=10 \mu \mathrm{m}$.

The polymeric metal complexes structure are:
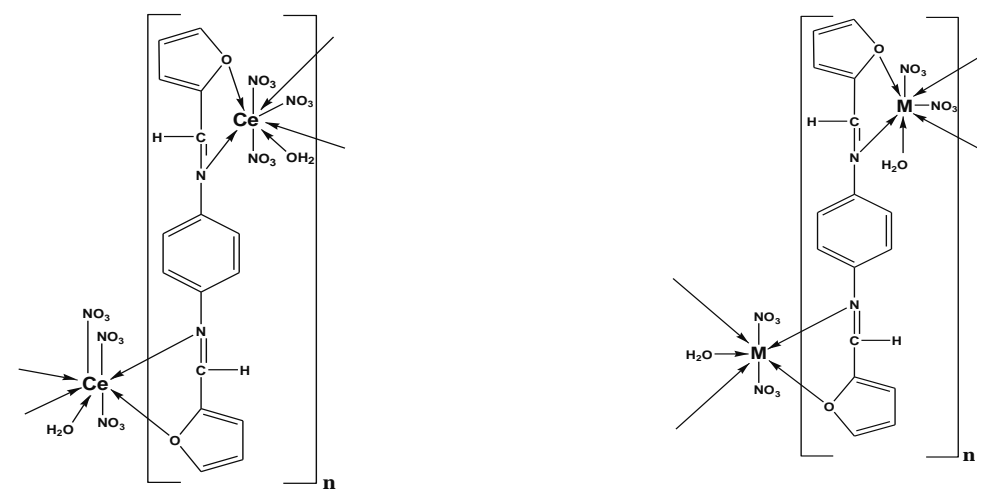

where $\mathrm{M}=\mathrm{Zn}(\mathrm{II})$ or $\mathrm{Cd}(\mathrm{II})$ in the right-hand structure. 


\section{Conclusion}

Coordination polymers of the Schiff base N, N bis-(Furan-2-ylmethylene)1,4-phenylene diamine (BFMPDA) with zinc(II), cadmium(II) and cerium(III) have been prepared in dioxane medium. The optimal $\mathrm{pH}$ conditions for preparation the polymeric complexes were determined by potentiometry study. The stability constants of the complexes formed were calculated from the obtained potentiometric data. Polychelates polymers formed have been characterized using elemental analysis, infrared and electronic spectra. The polymers have high glass transition temperature $(\mathrm{Tg})$ and thermal stabilities. Electrical conductivity measurements of the synthesized polychelated polymers showed that they are insulators. The metal contents in all polymers are found to be consistent with 1:1 metal:ligand stoichiometry. The solubility and viscosity of the polymer complexes were also determined. Scanning electron microscopy (SEM) on the surface of the synthesized samples supported the structural studies of these polymeric complexes. The analytical results indicate that the synthesized coordination polymers posses the general formulas [Zn (BFMPDA) $\left(\mathrm{NO}_{3}\right)_{2}$ $\left.\left(\mathrm{H}_{2} \mathrm{O}\right)\right]_{\mathrm{n}}$, $\left[\mathrm{Cd}(\mathrm{BFMPDA})\left(\mathrm{NO}_{3}\right)_{2}\left(\mathrm{H}_{2} \mathrm{O}\right)\right]_{\mathrm{n}}$ and $\left[\mathrm{Ce}(\mathrm{BFMPDA})\left(\mathrm{NO}_{3}\right)_{3}\left(\mathrm{H}_{2} \mathrm{O}\right)\right]_{\mathrm{n}}$.

\section{References}

1. Jian, X., Xiao, L., Zhow, W. and Xu, F., Polym. Bull, 63, 225 (2009).

2. Mariano, R.M., Oliverap, M. R. L., Rubiyger, M.M.M. and Vscante, L. L. Y., Eur. Polym. J. 43, 4706 (2007).

3. Demirbas, U., Kurt, A., Sennaroglu, A., Yilgőr, E. and Yilgor, I., Polymer, 47, 982 (2006).

4. Grimes, S. M. , Polym. Degrad. Stab. 91, 3274 (2006).

5. Arimato, F. S. and Haven, A.C., J. Am. Chem. Soc. 77, 6295 (1955).

6. Dragutan,V., Dragutan, I. and Fischer, H., J. Inorg. Organomet. Polym. 18, 18 (2008).

7. Geckeler, K., Weingartner, K. and Bayer, E., Pure Appl. Chem. 52, 1883 (1980).

8. Efendiev, A. A. and Kabanov, V.A., Pure Appl. Chem. 54, 2077 (1980).

9. Wolf, P. and Mallon, H.J., Acta Hydrochim. Hydrobiol. 9, 467 (1981).

10. Hughes, M.N., The Inorganic Chemistry of Biological Processes, p. 416 Wiley; New York (1981).

11. Sigel, H., “ Metal Ions in Biological System”. p. 168, Marcel Dekker; New York (1981).

12. Williams, D.R., "The Metals of Life”, p. 236. Van Norstrand Reinhold, Princeton, N. J. (1971).

Egypt. J. Chem. 54, No.3 (2011) 
13. Lettimer, R. L. and Kroenke, W. J., J. Appl. Polym. Sci. 26, 1191 (1981).

14. Patel, M. N. and Jani, B. M., J. Macromol. Sci.Chem. A22, 1517 (1985).

15. Patel, R.D., Patel, H. S. and Patel, S.R., Eur. Polym. J. 23, 229 (1987).

16. Patel, N.H., Patel, K.N. and Patel, M.N., Synth. React. Inorg. Met. Org. 31 (6), 1031 (2001).

17. Patel, N.H., Patel, K.N., Patel, K.M. and Patel, M.N., Synth. React. 32(10), 1879 (2002).

18. Jứnior, G.C., Silva, A.P.S. and Guinesi, L.S., Polyhedron, 23, 1923 (2004).

19. Abd-El-Aziz, A. S. , Macromol. Rapid. Commun. 23, 995 (2002).

20. Abd-El-Aziz, A. S. and Todd, E.K., Coord. Chem. Rev. 246, 3 (2003).

21. Abd-El-Aziz, A.S., Okasha, R. M. and Afifi, T. H., J. Inorg. Organomet. Polym. Mater. 14, 269 (2004).

22. Abd-El-Aziz, A. S. and Manners, I., J. Inorg. Organomet. Polym. Mater. 15, 157 (2005).

23. Abd-El-Aziz, A. S., Sarruthers, S. A., Aguiar, P.M. and Kroeker, S., J. Inorg. Organomet. Polym. Mater. 15, 349 (2005).

24. Puddephatt, R. J., J. Inorg. Organomet. Polym. Mater. 15, 371 (2005).

25. Wolf, M.O., J. Inorg. Organomet. Polym. Mater. 16, 189 (2004).

26. Wong, W. Y., Coord. Chem. Rev. 249, 971 (2005).

27. Kaliyappan, T. and Kannan, P., Prog. Polym. Sci. 25, 343 (2000).

28. Methenitis, C., Morcellt, J., Pneumatikakis, G. and Morcellt, M., Eur. Polym. J. 39, 687 (2003).

29. Roma-Luciow, L., Sarraf, L. and Morcellt, M., Eur. Polym. J. 37, 1741 (2001).

30. Santana, A. L., Noda, L.K., Pires, A.T.N. and Bertolino, J. R., Polym. Test. 23, 839 (2004).

31. Watanabe, A., Miyashita, T., Kasuya, A., Takahashi, M. and Kawazoe, Y., Polymer, 49, 554 (2008).

32. Li, B., Zhu, X., Zhou, J., Peng, Y. and Zhang, Y., Polyhedron, 23, 3133 (2004).

33. Kuo, P., Liang, W. and Chen, T. , Polymer, 44, 2957 (2003).

34. Mun, G.A., Nurkeeva, Z.S., Khutoryanskiy, V.V., Sarybayeva, G.S. and Dubolazov, A. V., Eur. Poym. J. 39, 1687 (2003). 
35. Sebastian, N., Gerge, B. and Mathew, B., Polym. Degrade. Stab. 60, 371 (1998).

36. Moustafa, M. H., Ass. Univ. Bull. Environ. Res. 8(1), 103 (2005).

37. Abd-Elmottaleb, M., El-Sayed, A. Y. and Moustafa, M.H. , Egypt J. Chem. 38(2), 195 (1995).

38. Irving, H. and Rossotti, H. S. , J. Chem. Soc. 2904 (1954).

39. Meites, L. “Handbook of Analytical Chemistry" McGraw-Hill, New York (1963).

40. Douheret, G., Bull. Soc. Chim. Fr. 3122 (1968).

41. Gans, P., Sabatini, A. and Vacca, A., J. Chem. Soc., Dalton Trans. 1195 (1985).

42. Hassan, M., Al-Azhar Bull. Sci. 12(2), 295 (2010).

43. Hassan, M. , Al-Azhar Bull. Sci. (AISC'08), 71 (March, 2008),

44. Hassan, M., Ass. Univ. Bull. Environ. Res. 13( 2), 77 (2010).

45. Gharbi, S. Andreolety, J. and Gandini, A., Eur. Polym, J. 36, 463 (2000).

46. Hui, Z. and Gandini, A., Eru. Polym. J. 28, 12, 1461 (1992).

47. Agarwal, R. K. and Agarwal, H., J. Saudi Chem. Soc. 5, 329 (2001).

(Received 3/ 4 /2011; accepted 13/10/2011) 


\title{
تحضير وتوصيف بعض البوليمرات التناسقية الجديدة مع قاعدة ثيف مشتقة من فيورفير ال \\ حمود حسن مصطفى ومحمد طارق عبدالله قسم الكيمباء- كلية العلوم - جامعة الأزئ هر - فرع أسيوط ـ أسيوط - مصر .
}

\begin{abstract}
يشتمل هذا البحث علي دراسات فيزيقوكيميائية علي منر اكبات بوليمرية جديدة تم

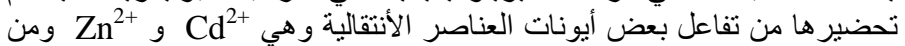

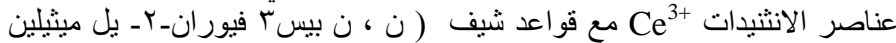

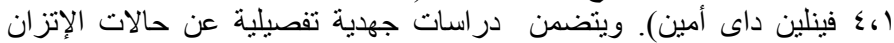

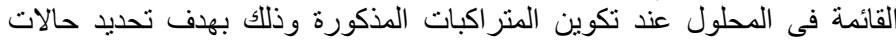

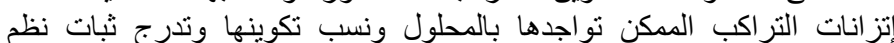

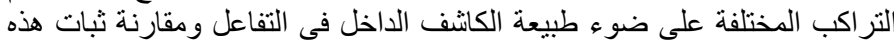

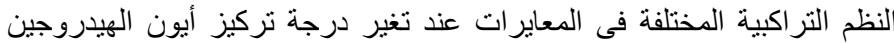

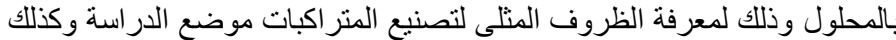

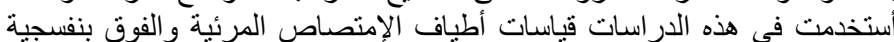

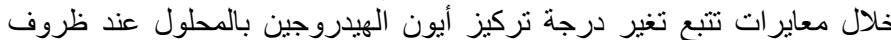

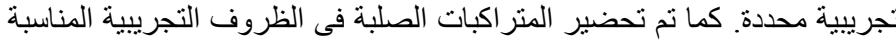

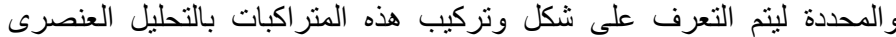

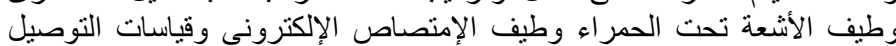
الجزئية و الكهربية و التحليل الحر ارى الوزنى و المسح الميكروسكوبى الإلكترونى. الإنى وقد بينت دراسة المتر اكبات الصلبة أن هذه المركبات هى سلاسل بوليمرات

